\title{
Students' Perception towards the Library User Education Programmes of the University of Moratuwa, Sri Lanka: A Case Study
}

\author{
C.N.D. Punchihewa ${ }^{1}$, K.G.A.P. Kiriella ${ }^{2}$, A.D.B. Kumara ${ }^{3}$, \\ Ruvini C. Kodikara ${ }^{4}$
}

\begin{abstract}
Library, University of Moratuwa has identified the importance of acquiring the user perception on different user education programmes offered by the library. The objective of this case study was to assess the students' perception and examine the impact of the user education programmes conducted. 'Library Orientation and Tour', 'Information for Research', 'Research and Plagiarism' and 'How to do Referencing' are the library user education programmes considered in this study. The participants were the undergraduate and postgraduate students, who have participated in the library user education programmes during 2014-2015. A user survey method was adopted in this study. Considering the size of the student group, 30\% of the total population (188) randomly selected for the study and online structured questionnaire was used to collect data. Results revealed that library user education programmes helped $98.7 \%$ of the students to obtain the awareness of library resources and services. In addition, more than $98 \%$ of the students claimed that library user education programmes support for their academic works. The study also highlighted the importance of continuing the library user education programmes in building research skills among the students to develop the research culture in the university.
\end{abstract}

Keywords: Academic libraries, Information literacy, Information skills, Library user education, Sri Lanka, University libraries

1 Senior Assistant Librarian, University of Moratuwa. Email: nishanp@uom.lk, (iD) https://orcid.org/0000-0002-8261-8001

2 Senior Assistant Librarian, University of Moratuwa. Email: anurap@lib.mrt.a.lk, DiD https:/orcid.org/0000-0001-7927-6189

3 Senior Assistant Librarian, University of Moratuwa. Email: buddhin@lib.mrt.ac.lk, (iD) https://orcid.org/0000-0003-1269-5252

4 Librarian, University of Moratuwa. Email: ruvinik@lib.mrt.ac.lk, https://orcid.org/0000-0001-6627-5427

Received: 7 March 2018, Accepted revised version: 3 July, 2018. 


\section{Introduction}

It is an accepted fact that academic libraries should have a clear understanding of research and scholarly needs of their academic user community. The library should identify the methodologies to increase the usage and access to the library resources which would result in enhancing the research culture of the university. As such libraries should market its resources to obtain the maximum benefits for the funds invested. The user education programmes could be used to increase the awareness of existing services and also to introduce new services.

User education programme is an essential service offered by academic libraries to their user community. As Brathwaite and Dolabaille (2013) and Klaib (2011) explained, the concept of the user education as introducing the library and its facilities to the patrons and training them effectively on accessing and using variety of information sources though it was named in different terminologies such as "library orientation", "library literacy", "information literacy" or "bibliographic instructions". Klaib (2011) has discussed the expected outcomes of the library user education programmes. According to him, library user education programme is, educating the library patrons to use the library effectively with bibliographic education and information literacy skills. Bibliographic education assists the patrons to identify the required information, its location and evaluation whereas information literacy instructions enhance the users' ability in recognizing information when it is needed and then locating, evaluating and using the required information effectively. User education programmes at university libraries offer subject related information, tutorials and other necessary instructions to the students to create awareness of library resources and to develop information literacy skills.

Analysis of circulation and shelving data, analysis of interlibrary loan requests and citation analysis were some of the quantitative techniques applied by the libraries to understand the patrons' needs. Other than applying those kinds of techniques, libraries have introduced different types of library user education programmes to enhance the usage and to popularize the library resources among the patrons. Efficient exploration and utilization of library resources depends on the patrons' awareness and understanding of 
library resources and patrons' skills to access the resources (Klaib, 2011; Ilo \& Idiegbeyan-ose, 2011). At this point, library user education programmes play a major role by providing instructions, education and training to the patrons to enhance their knowledge of library resources and to develop their information literacy skills. User education is about equipping users with the skills to exploit archival resources to meet their own information needs.

The aim of this study is to investigate how user education programmes conducted by the library of the University of Moratuwa, Sri Lanka have influenced the students in their educational and research activities, and also to identify the students' attitudes and perceptions towards the library user education programmes which will require future visions. The feedback of the respondents, would be helpful to remove the unnecessary components of the user education programmes and include or introduce new components for the betterment of future programmes.

\section{Research Objectives}

Purpose of this study was to investigate the students' perception of user education programmes offered by the library, University of Moratuwa and to examine the impact of such library user education programmes on students. The specific objectives of the study were to:

i. Investigate the level of awareness among students regarding the user education programmes of the library

ii. Assess the students' perception on library user education programmes

iii. Identify the usefulness of library user education programmes

\section{Literature Review}

Association of College and Research Libraries (ACRL) (2000) defines information literacy as "a set of abilities requiring individuals to recognize when information is needed and have the ability to locate, evaluate, and use effectively the needed information". As 'information literacy programmes' and 'user education programmes' are two different terms used for similar kind of programmes, Morris (Ilo \& Idiegbeyan-ose, 2011) has expressed the same idea by defining user education as the instructions provided to patrons to explain the best possible ways of using the library and its resources. He has divided library user education into two types, library orientation and 
bibliographic instructions. According to him, library orientation is defined as the general introduction of library resources and services to the patrons and bibliographic instruction is introducing the best possible ways of accessing the resources. Klaib (2011) claimed, library user education programme is, educating the library patrons to use the library effectively with bibliographic education by improving the patrons' information literacy skills.

Klaib (2011) has discussed the differences in theoretical objectives and practical objectives of library orientation programmes as:

theoretical objectives are achieved through activities with a set of abilities that provide the library users with theoretical knowledge to enable them to know several ideas about the library such as library services and how to benefit from them; library instructions; library departments; library printed collections; electronic library collection; library catalogue; the importance of information on students' academic achievement; the importance of library in supporting search skills; the importance of reading and promoting reading; finding out information sources; and defining the needed information.

and

practical objectives are achieved through activities with a set of abilities that provide the users with practical skills aimed at allowing students the opportunity to apply theoretical knowledge obtained in the academic programme to practical work. The activities are designed to improve students' future performances, and develop, through research and professional experience, a sense of what they are striving to achieve, and also how to collect the data that will help them meet these goals by supporting the learning process and helping translate knowledge into action manifested in information skills.

There are many advantages to the libraries in providing user education programmes for library patrons. As Lamptey (2010) mentioned, usage and demand for library resources will be increased by improving the patrons' awareness and skills required to explore the library resources. He has emphasized the importance of conducting library orientation programmes for first-year students and advanced instruction methods in information 
searching, research writing and referencing etc. for postgraduate students. Sanni et al. (as cited in Ilo \& Idiegbeyan-ose, 2011) further discussed the benefits of user education programmes for the libraries. They mentioned that user education programmes will help to popularize the library and improve the library image among the patrons. Moreover, user education process helps the librarians to familiarize the users with library resources. In addition, Librarians will have the opportunity to apply various teaching techniques in conducting user education programmes.

Several studies have been conducted to identify the techniques that could be applied in library user education programmes. After conducting a study at King Fahed University for Petroleum and Minerals in Saudi Arabia by Ashoor (2005),"library orientation programme", "library tour for students and new faculty members", "educational programmes" and "courses on scientific research skills" were identified as necessary components in any library instruction programme. Kraemer, Lombardo, and Lepkowski (2007) at Oakland University, USA compared the impact of three different types of library instruction programmes, namely "online instructions", "live instructions" and "hybrid combinations" on their patrons. They found that hybrid instructional model was the most comprehensive instructional method and with that method, librarians can use multiple teaching and learning styles, latest technology etc. while maintaining the physical contact with the students. Aina (2004) suggested three different methods that could be applied in library user education programmes, such as "one-to-one session", "library orientation and tours" and "classroom instructions".

User education programmes in Sri Lankan universities have a very short history. Though the concept of information literacy or user education was discussed in many universities around the world since 1980s, this concept was recognized and introduced in Sri Lankan libraries very lately in 2004 (Ranaweera, 2010), followed by the International Workshop on 'Information Skills for Learning' organized by the National Institute of Library and Information Science (NILIS), University of Colombo. Ranaweera (2010) also pointed out the key areas of the user education programmes conducted by many Sri Lankan university libraries. They are: 
how to locate resources, information resource selection, searching electronic databases, search strategies, Internet searching and source evaluation, critical evaluation of information, how to avoid plagiarism, academic integrity, academic writing and preparing a research proposal (Ranaweera, 2010).

Sri Lankan university libraries conduct user education programmes to achieve similar objectives without any collaborative efforts among them. Presently, all the university libraries in Sri Lanka are conducting user education programmes for their patrons using different methods. Ratnayake (2004) has conducted a survey to identify the different user education programmes conducted by university libraries. He observed that such programmes were focused only first-year undergraduate students, with an introductory session followed by a library tour. Hindagolla (2013) highlighted the gap between patrons' expectations and user education programmes offered by the Main library of the University of Peradeniya, while mentioning the lack of ability in providing proper awareness of library resources and services. The results of the study conducted by Ranaweera (2010) in relation to information literacy programmes of Sri Lankan Universities, by comparing five government universities in Sri Lanka, has revealed the difficulties in integrating information literacy with the university curriculum. However, Nawarathne and Singh (2013) highlighted the success of the information literacy programme which was commenced as a credit-bearing course for undergraduate students at the Department of Languages in the University of Sabaragamuwa.

\section{User Education Programmes at University of Moratuwa}

The library at the University of Moratuwa was established in year 1972. Though, planned user education programmes were introduced in the year 2002. As Seneviratne (2009) stated, before year 2000, the librarian's address in the form of common lecture for all the new undergraduate students was considered as the user education programme. Since 2000, student handbook was provided for easy reference in addition to common lecture. Library tours were organized on request of the departments. In 2002, library initiated user education sessions for all patron categories, with the intention of increasing the user awareness on library resources, library web, online catalogue and 
online resources. These sessions were conducted in the library, common lecture halls and in few academic departments. User Education Unit (UEU) of the library was established in 2006 and commenced its orientation programme for first-year Engineering students and National Diploma in Technology (NDT) students in the same year (Seneviratne, 2009).

Presently, library is conducting several user education programmes, considering the modern information needs of the patrons with the support of latest advanced technologies available. User education programmes conducted at present by the UEU of the library are described in detail as follows:

\section{Library Orientation and Tour}

The orientation programme of the library is designed to develop the students' knowledge and skills needed to find library resources independently. This library orientation programme includes two sessions, an introductory session with a library tour and a practical session at the computer lab for new undergraduate as well as postgraduate students. Generally, introductory session of the library orientation programme provides an introduction to the layout of the library, different resources, facilities and service points, checkin and check-out procedures, various library services, how to request books and articles, etc. Library tour allows the students to experience the various sections of the library, which is guided by a library staff member. Hands-on training to improve their searching skills in relation to library catalogue, library web and other online resources also given in a computer laboratory during the practical session. In order to evaluate whether the delivered knowledge has been grasped by the students, an assignment is given to locate a particular subject related information resources within the library premises.

\section{Information for Research}

The target group of this user education programme is final year undergraduates and postgraduate students who are seeking information for their research. Different types of information sources related to their subject fields and proper techniques to search and evaluate relevant information from the Internet and other resources are introduced in this session. As each 
student needs to master the search engines on their own, this session is conducted as a practical session in a computer laboratory.

Research and Plagiarism

The purpose of this session is to create an in-depth knowledge on 'plagiarism' and 'how to avoid plagiarism', which is necessary for producing quality research outputs. Since the university has made it compulsory to check the similarity of all research work using anti-plagiarizing software 'Turnitin', this session is important for all undergraduate and postgraduate students.

\section{How to do Referencing}

As university has adopted the referencing styles of the American Psychological Association (APA) and Institute of Electrical and Electronic Engineers (IEEE), this session gives an opportunity for the students to obtain a clear understanding of these referencing styles with practical examples.

University of Moratuwa admits students from various parts of the country, urban areas as well as rural areas of the country with different backgrounds. Among these students, some have acquired skills to use library resources, Internet and library catalogue, whereas others have many difficulties in locating library resources due to various reasons such as lack of skills in using Internet and computers. Therefore, library of the University of Moratuwa decided to conduct several user education programmes for students to overcome these difficulties. However, the library has noticed that still some students are struggling in accessing and utilizing library resources. Often, they request the assistance of library staff in locating library items and unfamiliar with the online catalogue of the library. As such this study intended to find out the lapses in training provided to them via user education programmes. Moreover, it is essential to assess the students' attitudes and perception regarding the quality of these library user education programmes and how effective these library programmes to their academic works which will be an advantage in improving the skill level of the students. 


\section{Methodology}

The survey research strategy was adopted in this study using structured questionnaire as data collection tool. The questionnaire was prepared to obtain demographic information, impact of user education programmes and students' perception on user education programmes. An online questionnaire was distributed through email to all the selected participants. Data analysis methods such as descriptive statistics and non-parametric tests were employed using SPSS-21 statistical analysis package.

Study population includes both undergraduate and postgraduate students who have participated in different library user education programmes during 2014-2015. The total population of the study consists 385 undergraduate students and 242 postgraduate students. Thirty percent $(n=188)$ of the total population selected as the study sample.

\section{Results}

In this study, questionnaires were distributed among 115 undergraduate students and 73 postgraduate students. The total response rate of the survey was $86 \%$ considering the questionnaires returned from 102 (95.3\%) undergraduate students and 60 (82.2\%) postgraduate students.

\section{Demographic Characteristics}

Demographic characteristics of the study sample are shown in Table 1. Ninety-six (59.3\%) female students and 66 (40.7\%) male students participated in the survey. Majority of the respondents (76.5\%) belonged to the age category 21-30. As other age categories (31-40 years, $41-50$ year and above 50 years) mentioned in the questionnaire have inadequate data to use in the statistical test, all three age categories were combined together to form a new age category called 'Above 30 years'. Subsequently, these two age categories were considered in the data analysis.

Majority of the responses received from the students of Faculty of Engineering (56.17\%) compared to Faculty of Architecture (41.98\%) and Faculty of Information Technology (1.85\%).

When considering the total student population of the university, Faculty of Engineering has the largest student group (University Grants Commission - 
Sri Lanka, 2018). Moreover, Faculty of Information Technology has not been considered for the study due to inadequate data for a statistical test.

Table 1. Demographic characteristics of the study sample

\begin{tabular}{crr}
\hline & Frequency & Percentage \\
\hline Gender & 66 & 40.70 \\
Male & 96 & 59.30 \\
Female & & \\
Age group & 124 & 76.50 \\
$21-30$ & 33 & 20.40 \\
$31-40$ & 4 & 2.50 \\
$41-50$ & 1 & 0.60 \\
Above 50 & & \\
Course & 102 & 63.60 \\
Undergraduate & 60 & 36.40 \\
Postgraduate & & \\
Faculty & 68 & 41.98 \\
Architecture & 91 & 56.17 \\
Engineering & 3 & 1.85 \\
IT &
\end{tabular}

Awareness among Students Regarding the User Education Programmes Results of the analysis according to the gender, faculty and course level of library user education programmes is displayed in Table 2.

Table 2. Student awareness on user education programmes

\begin{tabular}{|c|c|c|c|c|c|c|c|}
\hline & & \multicolumn{2}{|c|}{ Library Orientation } & \multicolumn{2}{|c|}{$\begin{array}{l}\text { Finding Information for } \\
\text { Research }\end{array}$} & \multicolumn{2}{|c|}{$\begin{array}{l}\text { How to avoid Plagiarism } \\
\text { and Referencing Styles }\end{array}$} \\
\hline & & Yes & & & No & Yes & No \\
\hline \multirow{2}{*}{$\stackrel{凶}{\omega}$} & Male & $46(69.7 \%)$ & & & $34(52.3 \%)$ & $25(40.3 \%)$ & $37(59.7 \%)$ \\
\hline & Female & $55(57.3 \%)$ & $41(42.7 \%)$ & $52(54.7 \%)$ & $43(45.3 \%)$ & $54(58.1 \%)$ & 39(41.9\%) \\
\hline \multirow{2}{*}{$\frac{\vec{\Xi}}{\vec{\Xi}}$} & Architecture & $46(67.6 \%)$ & $22(32.4 \%)$ & $50(73.5 \%)$ & $18(26.5 \%)$ & $30(45.5 \%)$ & $36(54.5 \%)$ \\
\hline & Engineering & $53(58.2 \%)$ & $38(41.8 \%)$ & 33(36.7\%) & $57(63.3 \%)$ & $49(56.3 \%)$ & $38(43.7 \%)$ \\
\hline \multirow{3}{*}{$\begin{array}{l}\tilde{\omega} \\
\stackrel{\Xi}{0} \\
ن\end{array}$} & Undergraduate & $62(60.2 \%)$ & 41(39.8\%) & $64(62.7 \%)$ & 38(37.3\%) & $60(61.2 \%)$ & 38(38.8\%) \\
\hline & Postgraduate & $39(66.1 \%)$ & 20(33.9\%) & $19(32.8 \%)$ & $39(67.2 \%)$ & 19(33.3\%) & $38(66.7 \%)$ \\
\hline & All & $\begin{array}{c}\text { 101(62.3\% } \\
\text { ) }\end{array}$ & 61(37.7\%) & $\begin{array}{c}83(51.2 \%) \\
*\end{array}$ & $\begin{array}{c}77(47.5 \%) \\
*\end{array}$ & $\begin{array}{c}79(48.8 \%) \\
* *\end{array}$ & $\begin{array}{c}76(46.9 \%) \\
* *\end{array}$ \\
\hline
\end{tabular}


Table 2 describes that $62.3 \%, 51.2 \%$ and $48.8 \%$ of the students participated for the library orientation, finding information for research and how to avoid plagiarism and referencing style programme, respectively. It shows that most of the students preferred to participate in the library orientation program than the other programmes. Most of the undergraduate students (more than 60\%) participated for 'finding information for research' and 'how to avoid plagiarism and referencing style programme' compared to the postgraduate students. Majority of the postgraduate students (66.1\%) participated for orientation programme.

\section{Students' Perception of Library User Education Programmes}

Students' perception of the 'Library user education programmes' were measured based on six questions. They were knowledge on online catalogue, knowledge on electronic resources, knowledge on print resources, knowledge on library services, content and duration of the user education programme.

\section{Table 3. Student perception on Library Orientation Programme}

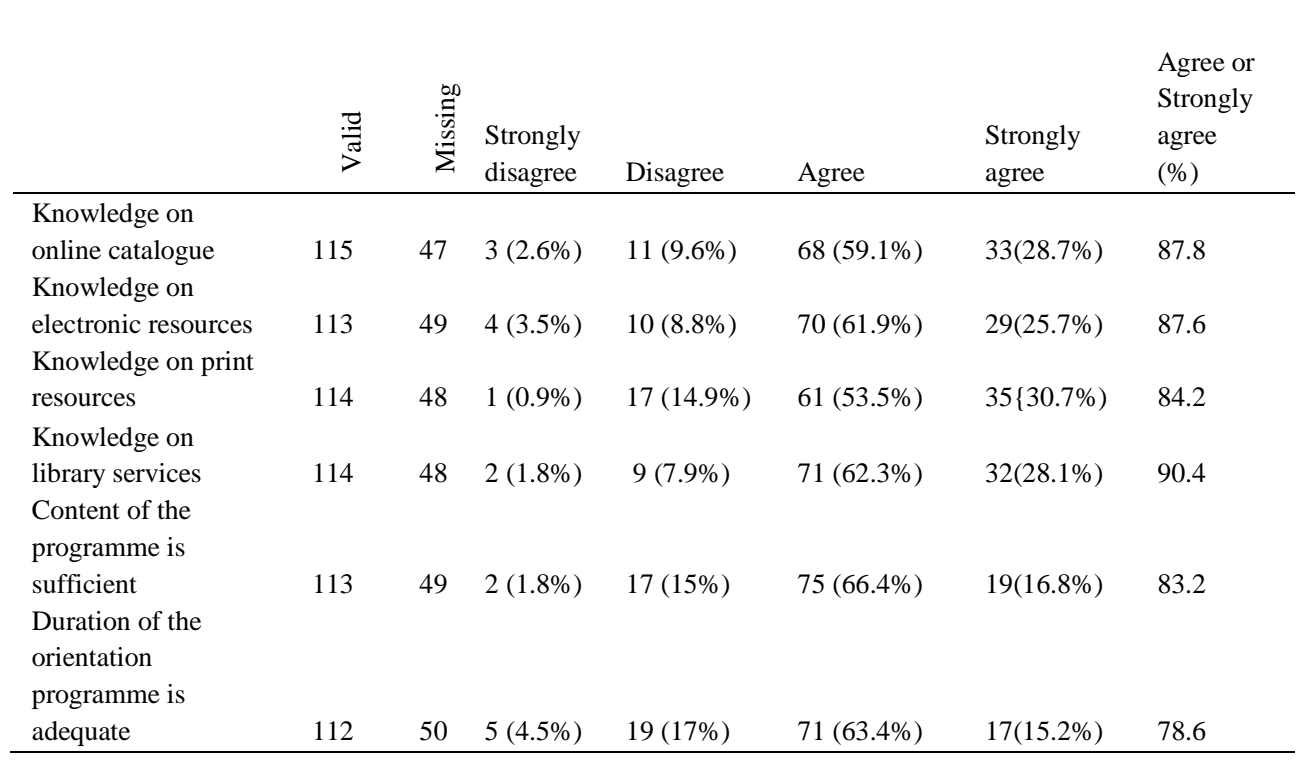

Total of 101 respondents (62.3\%) participated in Library Orientation Programme. Table 3 represents the perception of the students on library orientation programme. According to the results, more than $84 \%$ of the 
students stated that they have obtained knowledge on online catalogue, electronic resources, print resources and library services through the orientation programme. Also, $83.2 \%$ of the students have pointed out that the content covered in the programme were sufficient. Further, $78.6 \%$ of the students' satisfied with the time allocated for the library orientation programme.

Students' perception regarding 'Information for Research Programme' is illustrated in Table 4. It shows that the majority of the students have the opinion that this programme enhancing their knowledge in identifying relevant and accurate information for their needs. By considering the students' responses of "agree" and "strongly agree", this was $93.5 \%$ of the total responses. Also, $91.1 \%$ of the students have stated that they were able to enhance their information searching skills after participating in this programme and students have agreed with the content of the programme. However, students are less satisfied with two-hour time allocation for hands on sessions compared to the other factors. With these skills, students will be able to explore the literature available in the library as well as in the Internet for their academic activities.

Table 4. Student perception on Finding Information for Research Programme

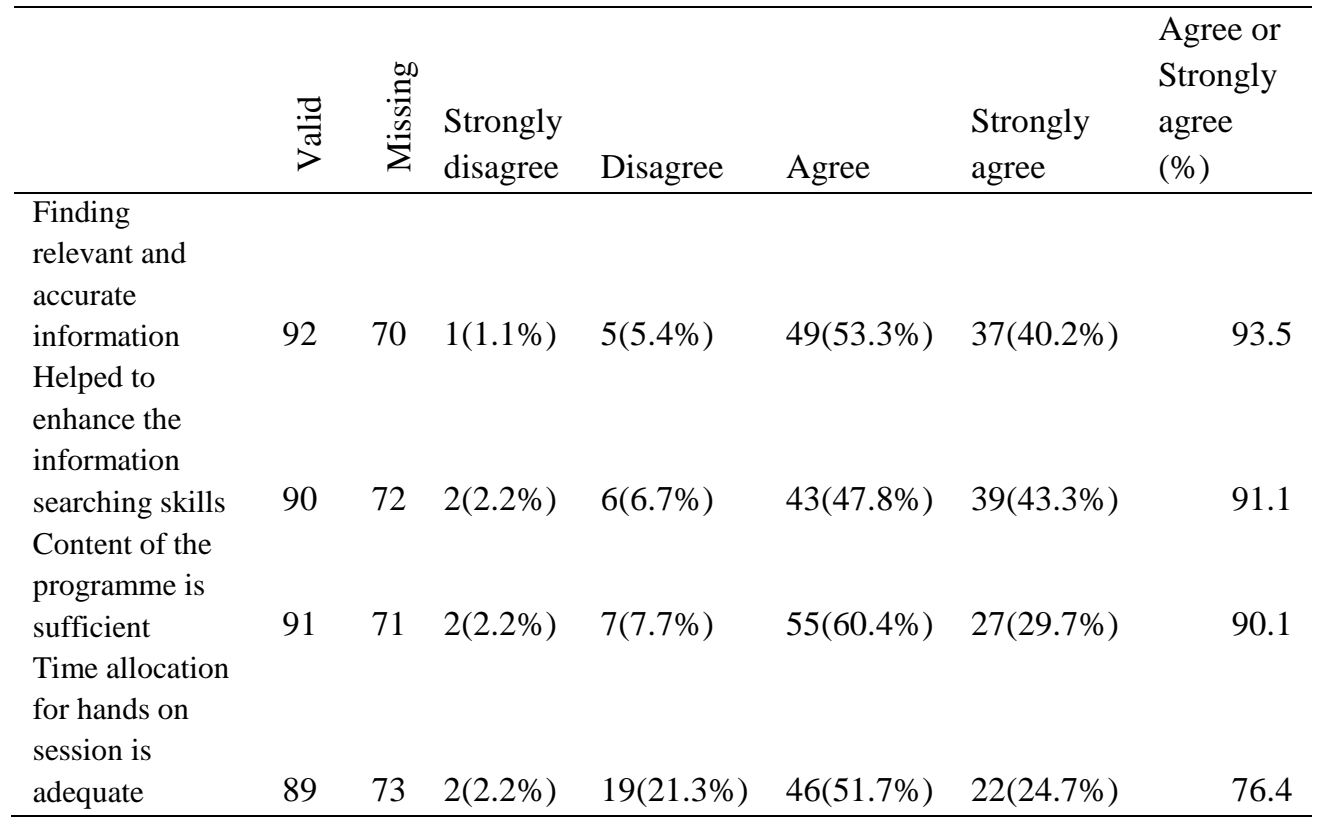


When undergraduate (UG) and postgraduate (PG) groups are considered separately, there is a significant (under 0.05 significance level) difference observed between UG and PG regarding the adequacy of the content (In the Kruska-Wallis test, Chi-square value: 6.583, df: 1 , sig-value: 0.010). It shows that $21.1 \%$ of the postgraduate students 'strongly disagree' or 'disagree'; however only $4.7 \%$ of the undergraduate students 'strongly disagree' or 'disagree'. Hence, content of the above programme has to be revised with regard to postgraduate students.

Table 5 demonstrates the students' perception regarding 'Research \& plagiarism' and 'How to do referencing' programmes. Results revealed that these programmes helped them to gain better knowledge of plagiarism (92.8\%) and referencing styles (95.2\%), in addition to obtaining confidence in handling citation tools (92.6\%).

Table 5. Student perception on Research \& Plagiarism and How to do Referencing Programmes

\begin{tabular}{|c|c|c|c|c|c|c|c|}
\hline & $\stackrel{\text { : }}{\supset}$ & 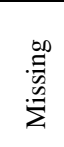 & $\begin{array}{l}\text { Strongly } \\
\text { disagree }\end{array}$ & Disagree & Agree & $\begin{array}{l}\text { Strongly } \\
\text { agree }\end{array}$ & $\begin{array}{l}\text { Agree or } \\
\text { Strongly } \\
\text { agree } \\
\text { (\%) }\end{array}$ \\
\hline $\begin{array}{l}\text { Gained knowledge on } \\
\text { plagiarism }\end{array}$ & 83 & 79 & $1(1.2 \%)$ & $5(6 \%)$ & $32(38.6 \%)$ & $45(54.2 \%)$ & 92.8 \\
\hline $\begin{array}{l}\text { Gained knowledge on } \\
\text { referencing styles }\end{array}$ & 84 & 78 & $1(1.2 \%)$ & $3(3.6 \%)$ & $37(44 \%)$ & $43(51.2 \%)$ & 95.2 \\
\hline $\begin{array}{l}\text { Gained confidence to } \\
\text { handle citation tools }\end{array}$ & 81 & 81 & $2(2.5 \%)$ & $4(4.9 \%)$ & $41\{50.6 \%)$ & $34\{42 \%)$ & 92.6 \\
\hline $\begin{array}{l}\text { Content of the programme } \\
\text { is adequate }\end{array}$ & 83 & 79 & $2(2.4 \%)$ & $5(6 \%)$ & $37(44.6 \%)$ & $39(47 \%)$ & 91.6 \\
\hline $\begin{array}{l}\text { Time allocation for hands } \\
\text { on session is adequate }\end{array}$ & 83 & 79 & 3(3.6\%) & $9(10.8 \%)$ & $45(54.2 \%)$ & $26(31.3 \%)$ & 85.5 \\
\hline
\end{tabular}

\section{Usefulness of Library User Education Programmes}

In view of improving the library user education programmes, it is essential to examine the students' opinion regarding the usefulness of these library user education programmes. Table 6 shows the students views about the usefulness of existing library user education programmes. 


\section{Table 6. Usefulness of library user education programmes}

\begin{tabular}{|c|c|c|c|c|c|c|c|}
\hline Programme & Valid & Missing & No idea & $\begin{array}{l}\text { Not } \\
\text { useful }\end{array}$ & Useful & $\begin{array}{l}\text { Highly } \\
\text { useful }\end{array}$ & $\begin{array}{l}\text { Useful } \\
\text { or } \\
\text { Highly } \\
\text { useful } \\
\text { (\%) }\end{array}$ \\
\hline \multicolumn{8}{|l|}{ Library } \\
\hline $\begin{array}{l}\text { Orientation } \\
\text { and Tour }\end{array}$ & 122 & 40 & $6\{4.9 \%)$ & $3\{2.5 \%)$ & $71\{58.2 \%)$ & $42\{34.4 \%)$ & 92.6 \\
\hline $\begin{array}{l}\text { Information } \\
\text { for Research }\end{array}$ & 128 & 34 & $4\{3.1 \%)$ & $6\{4.7 \%)$ & $65\{50.8 \%)$ & $53\{41.4 \%)$ & 92.2 \\
\hline $\begin{array}{l}\text { Research } \\
\text { and }\end{array}$ & & & & & & & \\
\hline Plagiarism & 117 & 45 & $11\{9.4 \%)$ & $5\{4.3 \%)$ & $52\{44.4 \%)$ & $49\{41.9 \%)$ & 86.3 \\
\hline \multicolumn{8}{|l|}{ How to do } \\
\hline Referencing & 119 & 43 & $6\{5 \%)$ & $5\{4.2 \%)$ & $52\{43.7 \%)$ & $56\{47.1 \%)$ & 91.4 \\
\hline
\end{tabular}

More than $91 \%$ of the students believed that 'Library orientation and tour', 'information for research' and 'how to do referencing' are useful or highly useful for their academic works. Besides, $86.3 \%$ of the students stated that 'research and plagiarism' helped them to imporve their academic writing.

Besides, students' attitudes regarding these user education programmes were also analyzed and results are given in Figure 1.

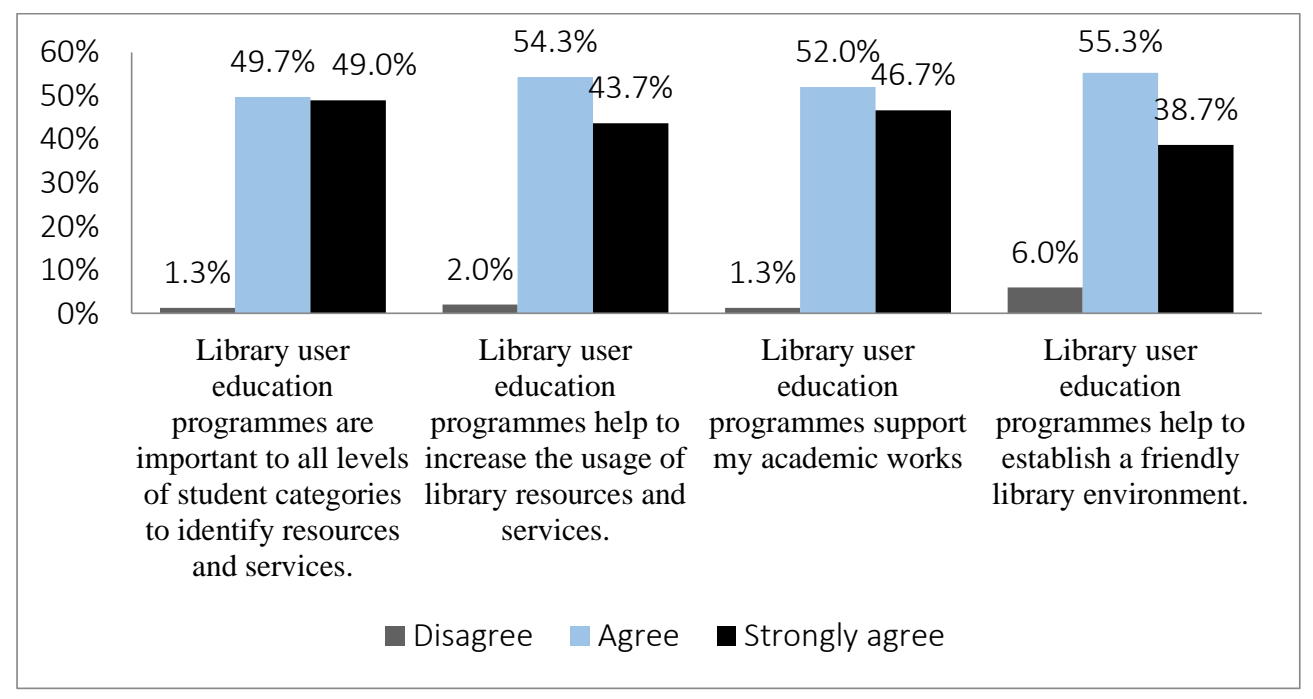

Figure 1. Students' attitudes on library user education programmes 
According to the results, $98 \%$ of the students stated that library user education programmes are important for all student categories to enable them to access the library resources and services. In addition, they mentioned that user education programmes increased their library usage and improved the quality of their academic works. Most importantly, 94\% of the students pointed out that user education programmes established a user-friendly environment within the library of the University of Moratuwa.

\section{Discussion}

Library user education programmes provide a valuable opportunity for the librarians to reach the faculty and students, and create awareness of library resources among them. In addition, this gives a chance for librarians to share their knowledge and experience in an academic environment.

User education programmes would minimize the 'library fear' among the new entrants to the university. Further, acquiring necessary skills required to locate the library resources and services through these programmes would enhance the utilization of the resources available in the library. Also, user education programmes would help to introduce physical layout of the library building, and basic reference tools available in the library with hands-on learning experience. Besides, it creates a user-friendly library environment to the students and facilitates to maintain a good relationship with the library staff.

According to the results of this study, majority of the students are satisfied with the contents and time duration of the library user education programmes. However, postgraduate students slightly (21.1\%) dissatisfied for the content of the 'Finding Information for Research' programme, and hence the content of the programme needed to be reconsidered. Students' participation in 'Finding Information for research', 'Research and Plagiarism' and 'How to do Referencing' was comparatively low. As these two programmes directly affect the quality of the research works of the students, the library should pay more attention to conduct these programmes continuously with the collaboration of the faculties while improving the content and the techniques to meet the needs of the students. 


\section{Conclusion}

Most of the students get the guidance and the assistance from the library, when they face difficulties in searching and locating information resources related to their work. Therefore, the library and the faculties should establish a collaborative mechanism to support students' assignments and projects through library user education programmes.

Also, the library should focus on introducing various new techniques related to library user education programmes, primarily the practical skills needed for the students to access the required information. This would encourage the library usage by the students as well. Further, the library should maintain a close relationship with the faculties to improve the quality of research, by imparting knowledge on information management, plagiarism and referencing. The library must also conduct user surveys on regular basis to obtain students' and faculties perception on user education programmes, which would enable to determine the changing pattern of information seeking behaviour of the user community.

\section{References}

Aina, L. O. (2004). Library and information science text for Africa. Ibadan, Nigeria: Third World Information Services.

Ashoor, M. (2005). Information literacy: A case study of the KFUPM library. The Electronic Library, 23(4), 398-409. https://doi.org/10.1108/02640470510611463

Association of College \& Research Libraries (ACRL) (2000). Information literacy competency standards for higher Education. Retrieved from http://www.ala.org/acrl/standards/informationliteracycompetency\#f1

Brathwaite, T., \& Dolabaille, A. (2013). Library orientation at the Alma Jordan Library: The way forward. Caribbean Library Journal, 1. Retrieved from http://uwispace.sta.uwi.edu/dspace/handle/2139/38257

Hindagolla, B. (2013). Restructuring of user education programmes in university libraries from user perspectives: a case study. Journal of the University Librarians Association of Sri Lanka, 16(1). https://doi.org/10.4038/jula.v16i1.5194 
Ilo, P. I., \& Idiegbeyan-ose, J. (2011). Library user education programme for Covenant University freshmen: Impact, challenges and possible solutions. Samaru Journal of Information Studies, 11(1-2), 7-12. https://doi.org/10.4314/sjis.v11i1-2

Klaib, F. J. (2011). Users' ratings on the improved library orientation programme at Zarqa Private University: A comparative study. Malaysian Journal of Library \& Information Science, 16(1), 63-72.

Kraemer, E. W., Lombardo, S. V., \& Lepkowski, F. J. (2007). The librarian, the machine, or a little of both: A comparative study of three information literacy pedagogies at Oakland University. College \& Research Libraries, 68(4), 330-342. https://doi.org/10.5860/crl.68.4.330

Lamptey, R. B. (2010). Promoting effective use of library resources and services at Kwame Nkrumah university of science and technology library, Kumasi, Ghana. Ghana Library Journal, 22(1-2), 87-99. https://doi.org/10.4314/glj.v22i1-2

Nawarathne, I. M., \& Singh, A. P. (2013). Information literacy programme conducted by the Sabaragamuwa University of Sri Lanka: General overview. International Journal of Information Dissemination and Technology, 2(4), 219-223.

Ranaweera, P. (2010). Information literacy programmes conducted by the universities in Sri Lanka. Journal of the University Librarians Association of Sri Lanka, 14(1). https://doi.org/10.4038/jula.v14i1.2688

Ratnayake, A. R. M. M. (2004). Library user education programmes in Sri Lankan universities: An overview. Journal of the University Librarians' Association of Sri Lanka, 8, 54-64.

Seneviratne, T. M. (2009). Going the extra mile: Information skills development at University of Moratuwa. Journal of the University Librarians Association of Sri Lanka, 13, 37-52.

University Grants Commission - Sri Lanka. (2018). Sri Lanka University Statistics 2016. Retrieved June 25, 2018, from http://www.ugc.ac.lk/en/component/content/article/1905-sri-lankauniversity-statistics-2016.html 